\title{
Summary Table of Contents
}

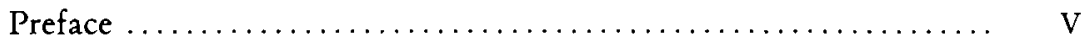

Acknowledgements $\ldots \ldots \ldots \ldots \ldots \ldots \ldots \ldots \ldots \ldots \ldots \ldots \ldots \ldots \ldots \ldots$ VI

Table of Cases $\ldots \ldots \ldots \ldots \ldots \ldots \ldots \ldots \ldots \ldots \ldots \ldots \ldots \ldots \ldots \ldots \ldots \ldots, \ldots \ldots \ldots$

\section{Part I: Community Policy-Making and Implementation Processes}

The Political Organs and the Decision-Making Process in the United States and the European Community

by Samuel Krislov, Claus-Dieter Ehlermann and Joseph Weiler ......

\section{Part II: Legal Techniques for Integration}

Instruments for Legal Integration in the European Community -

A Review

by Giorgio Gaja, Peter Hay and Ronald Rotunda

Conflict of Laws as a Technique for Legal Integration

\section{Part III: Judicial Process}

The Judicial Branch in the Federal and Transnational Union: Its Impact on Integration

by Mauro Cappelletti and David Golay

A Cumulative Index is to be found in Book 3 
